\title{
Are sea surface temperature satellite measurements reliable proxies of lagoon temperature in the south pacific?
}

\author{
Van Wynsberge Simon ${ }^{1,{ }^{*} \text {, Menkes Christophe }}{ }^{2}$, Le Gendre Romain ${ }^{3}$, Passfield Teuru ${ }^{4}$, \\ Andréfouët Serge ${ }^{5}$
}

${ }^{1}$ Institut de Recherche pour le Développement, UMR 9220 ENTROPIE (Institut de Recherche pour le Développement, Université de la Réunion, Centre National de la Recherche Scientifique), Arue, 98713, French Polynesia, France

2 Institut de Recherche pour le Développement, New Caledonia - Sorbonne Université (UPMC, Université Paris 06) - CNRS-MNHN, LOCEAN Laboratory, Nouméa, 98848, Paris, France

${ }^{3}$ IFREMER, Unité de Recherche Lagons, Ecosystèmes et Aquaculture Durable, Nouméa, 98848, NewCaledonia, France

${ }^{4}$ Ministry of Marine Resources, Pearl Support Division, PO Box 85, Avarua, Rarotonga, Cook Islands

${ }^{5}$ Institut de Recherche pour le Développement, UMR 9220 ENTROPIE (Institut de Recherche pour le Développement, Université de la Réunion, Centre National de la Recherche Scientifique), Nouméa, 98848, New-Caledonia, France

* Corresponding author : Simon Van Wynsberge, email address : simon.vanwynsberge@gmail.com

\begin{abstract}
:
In remote coral reef environments, lagoon and reef in situ measurements of temperature are scarce. Sea Surface Temperature (SST) measured by satellite has been frequently used as a proxy of the lagoon temperature experienced by coral reef organisms (TL) especially during coral bleaching events. However, the link between SST and TL is poorly characterized. First, we compared the correlation between various SST series and TL from 2012 to 2016 in three atolls and one island in the Central South Pacific Ocean. Simple linear correlation between SST and TL ranged between 0.44 and 0.97 depending on lagoons, localities of sensors, and type of SST data. High-resolution-satellitemeasurements of SST inside the lagoons did not outperform oceanic SST series, suggesting that SST products are not adapted for small lagoons. Second, we modelled the difference between oceanic SST and TL as a function of the drivers of lagoon water renewal and mixing, namely waves, tide, wind, and season. The multivariate models reduced significantly the bias between oceanic SST and TL. In atoll lagoons, and probably in other hydrodynamically semi-open systems, a correction taking into account these factors is necessary when SST are used to characterize organisms' thermal stress thresholds.
\end{abstract}




\section{Highlights}

- Oceanic satellite SST are not good proxies of lagoon temperature. Using SST can provide inaccurate maximal temperatures and thermal stress thresholds. Modelling $\Delta \mathrm{T}$ as a function of tide, waves, and wind speed helps to reduce the bias.

Keywords : Atoll lagoon, Pacific islands, Reef aperture, Climate change, Sea surface temperature 


\section{Introduction}

Understanding the vulnerability and resilience to climate change of coral reef organisms requires an accurate and long term characterization of the temperature they experience $\left(\mathrm{T}_{\mathrm{L}}\right)$ on reefs and in lagoons (Doney et al., 2012). In remote coral reefs, unfortunately, temperature series from in situ sensors and data loggers are usually lacking, or they are often short and interrupted due to logger failure, maintenance and access constraints (but see Berkelmans et al., 2002; Hendee et al., 2006). To get the long term and continuous series necessary to answer climate-change questions in particular, satellite-derived Sea Surface Temperature (hereafter SST) products have been used instead of $\mathrm{T}_{\mathrm{L}}$. Satellite products are available since the 70 s without interruptions, even for the most remote coral reefs where long term in situ data are unavailable. These measurements are therefore useful to coral reef biologists to relate biological processes (e.g., bleaching event, mass mortalities) with unusually high (or low) seawater temperature that may have exceeded some thermal resistance threshold for the organisms at stake (Logan et al., 2012, Van Hooidonk and Huber, 2009). Yet, the link between the two variables $\mathrm{T}_{\mathrm{L}}$ and $\mathrm{SST}$ is far from being trivial.

The two variables $T_{L}$ and SST are fundamentally distinct because they are not affected by the same processes. Satellite-derived SST is the temperature of a thin boundary layer at the air-sea interface $(\approx$ $0.01 \mathrm{~mm}$, the "skin layer"), and may not be appropriate to study nearshore subtidal habitats in case of vertical stratification of temperature (Small and Wernberg, 2009). The spatial resolution of SST data also matter, because spatially restricted fluctuations in temperatures induced by local processes (e.g., tides, upwellings) cannot be always adequately captured by coarse-resolution SST (Small and Wernberg, 2009). Finally, the value of SST for small size lagoons (few $\mathrm{km}^{2}$ or less) is unclear compared to the resolution of SST datasets. High resolution SST products $(1 \mathrm{~km})$ may provide some measurements inside the lagoons, but thus far the accuracy of time-series remains unclear for most areas, especially if the signal can be polluted by environmental effect due to presence of land, large tidal range exposing variable surface areas of intertidal domain, and spatial pixel-per-pixel 
misregistration. As a result, offshore open-ocean SST are commonly used as a proxy for shallow reefs and lagoon temperature in a variety of reef studies, including those related to climate change (Logan et al., 2012).

The renewal of lagoon water is primarily driven by tide and waves. Water inflow is prominent when ocean water level is above the lagoon water level, and vice versa. The higher the offshore tidal range, the stronger the water inflow and outflow to equilibrate the water levels between ocean and lagoon. Offshore waves (generated by distant storms or locally by wind) can also enhance lagoon water renewal because high waves bring water above the reef edges (Lowe and Falter, 2015). The intensity by which tide and waves determine the mixing between ocean and lagoon waters also strongly depends on the reef configuration itself. First, the nature of reef edges (reef passes, submerged reef flats, shallow channels) and their abundances determine the amount of water that can cross the reef. Second, the volume of exchange compared to the volume of the lagoon determines the extent by which oceanic waters influence lagoon waters. From these considerations, the linkages between $T_{L}$ and SST may not be the same for all lagoons, due to variable water renewal time that can range from few hours to several weeks or months (Andréfouët et al., 2001a).

Finally, it is important to point out that wind also drives lagoon circulation and mixing by setting into motion the upper water layer, promoting exchanges at the water-atmosphere interface (Dumas et al., 2012). This role is critical for closed water bodies. Strong wind also promotes stronger vertical mixing of lagoon waters. In enclosed lagoons under limited influence from the ocean, a thermocline (usually < $5 \mathrm{~m}$ depth) can form during low wind periods, but this thermocline quickly disappears when the wind increases (Dumas et al., 2012).

Tide, waves, wind regimes, and reef geomorphology may therefore modulate the correlation between $T_{L}$ and oceanic SST, especially when $T_{L}$ is measured at a given point and a given depth inside the lagoon, where benthic communities of interest are located. In this study, we first compared the correlation between various SST series and $\mathrm{T}_{\mathrm{L}}$ from 2012 to 2016 in three atoll lagoons and one island lagoon in the Pacific Ocean. This was performed for oceanic SST series and for lagoon SST series. 
Because SST poorly matched $T_{L}$ for some lagoons, we further modelled $T_{L}$ from oceanic SST, offshore tide, waves and wind. To our knowledge, this exercise has never been undertaken. This model should clarify in our context the validity of using SST and, in a broader context, should help understanding SST limits when little knowledge of the exact physical processes operating in the focal area is available. Here, we looked for an empirical relationship to characterize lagoon temperature, targeting especially the needs of ecologists, but that should not preclude that analytical characterization and numerical modelling can also be investigated when possible. Finally, we discuss the consequences of the observed differences between $T_{L}$ and SST when defining temperature-related variables of interest for ecologists.

\section{Methods}

\subsection{Study sites}

Our study focused on four lagoons in the Central Pacific (Fig. 1). The lagoon of Tubuai $\left(90 \mathrm{~km}^{2}\right)$ located in Austral Archipelago, French Polynesia, is open because it is permanently connected to oceanic waters through a large subtidal reef flat, or shallow pass, in the northern part of the lagoon, and two narrow shallow passes at the southwest end of the lagoon (Fig. 1D). All other reef edges consist in intertidal crests, therefore exposing the lagoon to waves especially at high tide and during periods of strong swell.

The atolls of Tatakoto and Takaroa in Tuamotu Archipelago, French Polynesia, are semi-closed atolls (Andréfouët et al., 2001b). The atoll rim of Tatakoto is closed in its northern part, but the lagoon $\left(11.46 \mathrm{~km}^{2}\right)$ is connected to the ocean by several shallow channels that bisect the southern part of the rim (Fig. 1B). The lagoon of Takaroa $\left(90 \mathrm{~km}^{2}\right)$ is closed, except by a narrow reef pass in the north and by several shallow channels in the south of the rim (Fig. 1C).

The atoll rim of Manihiki in the Cook Islands has no pass but the lagoon $\left(40 \mathrm{~km}^{2}\right)$ is connected to oceanic waters through large submerged reef flats in both the northwestern and southern part of the 
lagoon (Fig. 1E). Manihiki is therefore an open atoll (Andréfouët et al., 2001a; 2001b; Callaghan et al., 2006).

\subsection{Temperature loggers}

The temperature experienced by benthic coral reef organisms $\left(T_{L}\right)$ was recorded by using temperature loggers deployed at the four sites. Several of the sensors also recorded pressure, which provided supporting information on the water levels inside lagoons. The exact positions, measurement types, mean depths, and deployment period of sensors are provided in supplementary material SM1.

At Tatakoto, one sensor (TAT3) recorded temperature and pressure in the south part of the lagoon (mean depth: $3.4 \mathrm{~m}$ ) from November 2012 to October 2014 and two additional temperature sensors (TAT1 and TAT2) were placed at the opposite ends of the lagoon (Fig. 1B) until June 2016 at 1.0 and $2.8 \mathrm{~m}$ depth.

At Takaroa, one sensor (TAK2) in proximity to the reef pass (Fig. 1C) recorded temperature and pressure from November 2012 to June 2015, and two additional sensors (TAK1 and TAK3) recorded temperature respectively in the south part of the lagoon until March 2016, and in an enclosed shallow basin located in the southwestern part of the atoll until January 2016.

At Manihiki, three sensors were deployed along the same pinnacle located in the middle of the lagoon, but at various depths (Fig. 1E). One sensor (MAN3) recorded temperature and pressure from October 2012 to December 2013 at 15-m (mean-depth), while two other sensors (MAN1 and MAN2) recorded temperature at 5 and $20 \mathrm{~m}$ depth from October 2012 to February and March 2015.

At Tubuai, one sensor (TWR2050 TUB3) recorded temperature and pressure from April 2013 to June 2015, on the top of a submerged coral patch located in the south-eastern part of the lagoon (Fig. 1D).

\subsection{Sea surface temperature time series}

We used three independent data sources for open-ocean SST time series at high spatial resolution. 
First, we used the daily SST data from the UK Met Office's Global, daily, Operational SST and Sea

147

148

149

150

151

152

153

154

155

156

157

158

159

160

161

162

163

164

165

166

167

168

169

170

Ice (OSTIA) SST analyses at 0.05 degrees (i.e. around $5 \mathrm{~km}$ ) resolution (Donlon et al., 2012; http://ghrsst-pp.metoffice.com/pages/latest_analysis/ostia.html).

Second, we used the Global, daily Multi-scale Ultra-high Resolution (MUR) SST analyses at 0.01 degree (around $1 \mathrm{~km}$ ) resolution (Chin et al., 2017; https://mur.jpl.nasa.gov/).

Third, we used the Global, daily Level 4 G1SST Global Foundation Sea Surface Temperature Analysis (Chao et al., 2009; https://podaac.jpl.nasa.gov/dataset/JPL_OUROCEAN-L4UHfnd-GLOBG1SST/) at $1 \mathrm{~km}$ resolution.

For the three datasets, SST were extracted from October 2012 to June 2016 to match our period of in situ measurements, and a mean was computed with two different spatial domains around the island/atoll. First, we averaged the daily data over a $1^{\circ}$ by $1^{\circ}$ grid around the four sites. Second, the daily mean was computed over a smaller grid of $0.15^{\circ}$ by $0.15^{\circ}$, located $0.15^{\circ}$ westward of each study site to avoid any effect of land on SST measurements (Fig. 2A-2C). The three datasets (OSTIA, G1SST and MUR) and the two spatial domains considered for computing the mean $\left(1^{\circ}\right.$ by $1^{\circ}$ and $0.15^{\circ}$ by $0.15^{\circ}$ ) provided 6 SST time series for each study site, respectively designated as OSTIA- $1^{\circ}$, OSTIA- $0.15^{\circ}, \mathrm{G} 1 \mathrm{SST}-1^{\circ}, \mathrm{G} 1 \mathrm{SST}-0.15^{\circ}, \mathrm{MUR}-1^{\circ}$ and MUR- $0.15^{\circ}$ throughout this manuscript (Fig. 2A-2C).

Since the high spatial resolution of the MUR datasets $(1 \mathrm{~km})$ also provided several SST measurements inside the lagoons (see supplementary material SM2), we also considered one lagoon SST series, designated as MURLAG throughout this manuscript. The MURLAG dataset was a subset of the MUR dataset, but averaging SST values inside lagoons only (Fig. 2D) instead of averaging SST values over the $1^{\circ}$ by $1^{\circ}$ and $0.15^{\circ}$ by $0.15^{\circ}$ grids described above (Fig. 2C).

To evaluate the extent by which the various SST series can be used as a proxy of $\mathrm{T}_{\mathrm{L}}$, the Pearson's correlation between SST and the daily mean of $\mathrm{T}_{\mathrm{L}}\left(\bar{T}_{L}\right)$ was computed using the cor function in stats package in R.3.1.0. 


\subsection{Offshore tide, offshore waves, and wind}

An offshore tide signal, composed from 32 harmonic constituents, was generated for each study site using a MARS hydrodynamic configuration (Lazure and Dumas, 2008) used in its barotropic (2D) mode. The spatial domain of the model $\left(130^{\circ} \mathrm{W}-170^{\circ} \mathrm{W} ; 4^{\circ} \mathrm{S}-30^{\circ} \mathrm{S}\right)$ covers the four study sites at a resolution $0.09^{\circ}$ in latitude and longitude. Bathymetry was derived from Etopo 5-minute gridded data and open boundaries were forced by the global tidal solution FES2012 (Carrère et al., 2012). For each site, the sea surface height above sea level was averaged over a $1^{\circ} \mathrm{x} 1^{\circ}$ window, subtracted by its mean over the study period (October 2012 - June 2016). We defined $\mathrm{TR}_{\mathrm{d}}$ as the difference of sea surface height between the highest tide and the lowest tide of the day. The mean tidal range (MTR) was also calculated, as the mean of $\mathrm{TR}_{\mathrm{d}}$ over the study period.

The significant height of wind and swell waves $(\mathrm{SWH})$ and mean wave direction $\left(\theta_{\mathrm{m}}\right)$ came from the wave model Wavewatch III (WW3) (Rascle and Ardhuin, 2013), every 3-hours and at $0.5^{\circ}$ lon x $0.5^{\circ}$ lat resolution. For both SWH and $\theta_{\mathrm{m}}$, the mean over a $1^{\circ} \mathrm{x} 1^{\circ}$ grid around the four sites was computed, and used to calculate the significant wave height of effective waves $\left(\mathrm{SWH}_{\mathrm{e}}\right)$, as the Significant Wave Height, but excluding waves whose direction is perpendicular to the shoreline of closed (emerged) sections of the atoll rims. These rim sections do not authorize exchanges between ocean and lagoon, hence the contribution of the waves impacting these sections to the ocean-lagoon fluxes can be neglected (Andréfouët et al., 2001a). $\mathrm{SWH}_{\mathrm{e}}$ was thus the significant wave height of waves from southsoutheast for Tatakoto $\left(90<\theta_{\mathrm{m}}<270\right)$, waves from south, southeast and northwest for Manihiki and Takaroa $\left(90<\theta_{\mathrm{m}}<360\right)$, and waves from all directions for Tubuai $\left(0<\theta_{\mathrm{m}}<360\right)$.

The zonal (U) and meridional (V) wind components were extracted from the ERA-Interim atmospheric reanalysis (http://www.ecmwf.int/en/research/climate-reanalysis/era-interim) available for the studied period (October 2012 - June 2016) every 6 hours. The mean was computed over a $1^{\circ} \mathrm{x}$ $1^{\circ}$ grid around each site, and wind speed (WS) was calculated as the square root of the sum of squares of $\mathrm{U}$ and $\mathrm{V}$. We did not consider wind direction as a relevant variable to include in the models, since 
wind direction is not expected to drive lagoon temperature in the same order of magnitude than wind speed (Dumas et al., 2012).

\subsection{Modelling the difference between $T_{L}$ and oceanic SST}

The difference between $\bar{T}_{L}$ and oceanic $\operatorname{SST}(\Delta \mathrm{T})$ was computed and modelled as a function of various parameters, following eq. 1.

$$
\bar{T}_{L}-S S T=T_{v} \sin \left(\frac{2 \pi}{365} \times(D O Y+c)\right)+s\left(T R_{d}\right)+s\left(S W H_{e}\right)+s(W S)
$$

Since $\Delta \mathrm{T}$ was affected by a strong seasonal trend (see results), a first model (model 1) expressed $\Delta \mathrm{T}$ as a seasonal function of the day of year (DOY) added to a constant (c), and the seasonal amplitude $\left(T_{v}\right)$. The parameters $T_{v}$ and c were fitted using the nls function of stat package, and the relevance of accounting for seasonality in the model was assessed by comparison of the Aikaike Information Criteria (AIC) with versus without the seasonal term.

Once the seasonal term was parameterized, we tested the effect of offshore wave, offshore tide, and wind on the intra-seasonal variability of $\Delta \mathrm{T}$ by modelling residuals of model 1 as smooth functions (notified " $s\left(\right.$ )" in eq. 1) of $\mathrm{TR}_{\mathrm{d}}$, WS and $\mathrm{SWH}_{\mathrm{e}}$ (model 2). The smooth functions were first considered one by one then all together, and were parameterized by using a generalized additive model fitted by the gam function of mgcv package. Colinearity of factors was not addressed because no relationship between $\mathrm{TR}_{\mathrm{d}}$, WS and $\mathrm{SWH}_{\mathrm{e}}$ was apparent (Supplementary material SM3). The relevance of these parameters in model 2 was assessed by comparison of the Aikaike Information Criteria (AIC) with them versus without them. The relative importance of each term was further evaluated by comparison of p.values provided by the summary.gam function. Fitted values of $\Delta \mathrm{T}$ were then used to infer lagoon temperature $\left(\widehat{T}_{L}\right)$, and a R-square term was calculated to assess the proportion of $\bar{T}_{L}$ 's variance explained by $\widehat{T}_{L}$. 
222

223

224

Satellite derived SST time series and lagoon temperature (both $\bar{T}_{L}$ from in situ sensors TAT1, TAK1, TUB3 and MAN1, and $\widehat{T}_{L}$ from modelling) were used to calculate three variables of interest in ecological studies. First, we identified the maximal daily temperature recorded during the study period $\left(T_{m}\right)$, because short-term acute extreme temperature may affect survival of coral reef organisms. Then, we computed NOAA Coral Reef Watch Program bleaching prediction indices by calculating the mean monthly maximum (MMM) and the HotSpot metric over the study period. These metrics are used to empirically predict bleaching of coral organism, and often to critically examine a posteriori if they were good predictors of bleaching (McClanahan et al., 2007; Eakin et al., 2010). For SST data and $\widehat{T}_{L}$, $\mathrm{T}_{\mathrm{m}}, \mathrm{MMM}$, and HotSpot were calculated across the same time period as those recorded by in situ sensors.

\section{Results and discussion}

\subsection{Correlation between $\bar{T}_{L}$ and SST}

The best correlations between $\bar{T}_{L}$ and SST were usually obtained when using the oceanic SST from OSTIA or MUR datasets (Table 1 ). The OSTIA- $1^{\circ}$ and OSTIA $-0.15^{\circ}$ series were very similar because the OSTIA dataset displayed little variability at small spatial scale (Fig. 2A; SM4; SM5). By contrast, MUR- $1^{\circ}$ could differ from MUR- $0.15^{\circ}$ (Fig. 2C; SM5), and surprisingly the latter showed poorer correlation with $\bar{T}_{L}$, especially for Manihiki. Lower correlations were obtained for the G1SST dataset than for the OSTIA and MUR datasets (Table 1). Indeed, the G1SST products displayed short term variations that poorly matched $\bar{T}_{L}$ from in situ sensors (SM5). The surprisingly lower ability of the 1km-resolution G1SST dataset to match with in situ sensors compared to the 5-km-resolution OSTIA dataset suggests that increasing the spatial resolution of SST measurements outside the lagoons do not necessarily inform better on temperature inside the lagoon. The MUR, G1SST, and OSTIA analyses also involve slightly different data streams, data quality control, and statistical interpolation 
247 procedures (multi-resolution variational Analysis for MUR, multi-scale two-dimensional variational

248 analysis for G1SST, and optimal interpolation for OSTIA; see Chao et al. 2009; Donlon et al. 2012;

249 Chin et al., 2017), that may have provided contrasted outputs.

250 Using the MURLAG lagoon SST dataset did not outperform the oceanic MUR-1 ${ }^{\circ}$ dataset for Tatakoto

251 and Tubuai and Manihiki, and only provided negligible improvements for Takaroa (Table 1; SM5).

252 Several features may explain the poor congruence between lagoon SST and $\bar{T}_{L}$. First, satellite

253 measurements inside the lagoon might be biased by emerged reefs and land (Miller et al., 2005).

254 Second, when the Infra-Red measurements are contaminated by clouds, only the 25-km resolution

255 Micro-Wave measurements are used to calculate SST in the MUR analysis, which do not provide a

256 spatial resolution fine enough to picture lagoons. Finally, the data quality control and statistical

257 interpolation procedures performed in MUR analyses are adapted for offshore waters, but not for small

258 lagoons dotted by small emerged structures. These results suggest that lagoon SST is not a reliable

259 proxy of $\bar{T}_{L}$ for small lagoons in the Central Pacific, and that oceanic SST remain in these cases the

260 only reliable basis to infer $\bar{T}_{L}$.

261 Regardless of the SST dataset considered, the correlations between $\bar{T}_{L}$ and SST were lower for

262 Tatakoto, Manihiki, and Takaroa, than for Tubuai (Table 1; SM5). The high correlation found at

263 Tubuai between temperature recorded in situ and oceanic SST is in agreement with previous studies

264 on well-flushed and open coastal areas (Van Hooidonk et al., 2012). However, our results also confirm

265 that oceanic SST time series poorly inform on lagoon temperature when lagoon and ocean water

266 masses are little connected.

The differences between $\bar{T}_{L}$ and oceanic SST presented a seasonal trend, with $\bar{T}_{L}$ usually higher than SST in summer, and $\bar{T}_{L}$ usually lower than SST in winter (Fig. 3). In summer, the shallow waters are 
atmosphere and the shallow waters cool more easily than open ocean waters. The seasonal amplitudes $\left(\mathrm{T}_{\mathrm{v}}\right)$ were a function of the in situ sensors and SST datasets used (Supplementary material SM6), but were higher for Tatakoto (from $1.01^{\circ} \mathrm{C}$ to $1.19^{\circ} \mathrm{C}, \mathrm{SM}$ ), than for Takaroa (from $0.21^{\circ} \mathrm{C}$ to $0.70^{\circ} \mathrm{C}$ ), Manihiki (from $0.16^{\circ} \mathrm{C}$ to $0.39^{\circ} \mathrm{C}$ ) and Tubuai (from $0.16^{\circ} \mathrm{C}$ to $0.27^{\circ} \mathrm{C}$ ). The higher seasonal trend recorded at Tatakoto compared to other sites probably resulted from lower connection between ocean and lagoon waters, and lower thermal capacity due to the small volume of Tatakoto's lagoon. Considering a seasonal term for modelling $\Delta \mathrm{T}$ improved significantly the model for Tatakoto $(\Delta \mathrm{AIC}$ up to 908 , SM6), Takaroa ( $\triangle \mathrm{AIC}$ up to 283$)$, and Tubuai $(\triangle \mathrm{AIC}=99)$, but this was not the case for Manihiki $(\triangle \mathrm{AIC}<0$ for most sensors and SST datasets used). Interestingly, spatial variability was noticeable at Takaroa, with a stronger seasonal trend recorded for sensor TAK3 located in the shallow enclosed basin ( $T_{v}$ from 0.57 to 0.70 ) than for the two other sensors in the main lagoon $\left(T_{v}\right.$ from 0.21 to 0.54$)$.

Detailed descriptions of tide, lagoon water level, waves and wind patterns that characterize the four sites are provided in Supplementary materials SM5 and SM7. Accounting for $\mathrm{SWH}_{\mathrm{e}}$ to model the intra-seasonal variability of $\Delta \mathrm{T}$ further improved models significantly for all sites when considering the OSTIA and MUR SST datasets (all p.values < 0.001, SM6), with stronger influence at Tatakoto, than at Takaroa, Manihiki and Tubuai. The influence of WS on $\Delta \mathrm{T}$ was also significant for all sites and most sensors and SST datasets used (SM6), but was stronger for Tatakoto ( $\triangle$ AIC from 86 to 242), than for Takaroa ( $\triangle \mathrm{AIC}$ from 14 to 119 ), Tubuai ( $\triangle \mathrm{AIC}$ from 17 to 118 ), and Manihiki ( $\triangle \mathrm{AIC}$ from 0.24 to 66 ). By contrast, the influence of $\mathrm{TR}_{\mathrm{d}}$ on $\Delta \mathrm{T}$ was of lower magnitude ( $\Delta \mathrm{AIC}$ from -1.89 to 31 ) compared to $\mathrm{SWH}_{\mathrm{e}}$ and WS (SM6).

Statistical models selected to infer $\widehat{T}_{L}$ explained up to $92 \%$ of $\bar{T}_{L}$ 's variance for Tatakoto, $94 \%$ for Takaroa, 95\% for Tubuai, and 77\% for Manihiki. These results highlight that considering a seasonal trend as well as tide, waves and wind forcing can help reduce the offset between SST and $\bar{T}_{L}$, but statistical models cannot entirely represent all processes that influence short-term variations of $\Delta \mathrm{T}$ (Supplementary material SM8). As a result, statistical models can be poorly skilled to infer $\bar{T}_{L}$ from 
SST for lagoons that display low seasonality in $\Delta \mathrm{T}$ (i.e., Manihiki), but they are very helpful to identify which forcing factors would be the most critical when studying a variety of lagoons.

In parallel to the same exercise we did here, to advance further and analytically characterize the intraseasonal variation of $\Delta \mathrm{T}$, we advocate when possible the use of numerical modelling which account for the thermodynamic processes at the ocean-lagoon and the atmosphere-lagoon interfaces (McCabe et al., 2010). However, such approach requires significant work to obtain a realistic configuration (Andréfouët et al., 2006) and is beyond the scope of the present paper.

\subsection{Consequences for ecological studies}

Differences between $\bar{T}_{L}$ and SST highlighted in the previous sections have clear implications for ecological studies requiring knowledge on temperature regimes such as coral bleaching or mass mortalities (Andréfouët et al., 2015). The values of $\mathrm{T}_{\mathrm{m}}$ calculated from SST were usually similar to the values of $\mathrm{T}_{\mathrm{m}}$ calculated from $\bar{T}_{L}$ for Tubuai, with less than $0.3^{\circ} \mathrm{C}$ difference (Supplementary material SM9). By contrast, the difference in $\mathrm{T}_{\mathrm{m}}$ was higher for Takaroa (from 0.3 to $0.8^{\circ} \mathrm{C}$ depending on $\mathrm{SST}$ datasets used), Manihiki (up to $0.9^{\circ} \mathrm{C}$ ), and reached $1.6^{\circ} \mathrm{C}$ for Tatakoto. Similarly, the differences between the MMM calculated from SST and MMM calculated from $\bar{T}_{L}$ reached $0.2^{\circ} \mathrm{C}, 0.5^{\circ} \mathrm{C}, 0.2^{\circ} \mathrm{C}$ and $0.6^{\circ} \mathrm{C}$ for Tubuai, Takaroa, Manihiki and Tatakoto respectively. This resulted in different values for the HotSpot metrics. The accumulation of HotSpot values of $1^{\circ} \mathrm{C}$ or more is used by NOAA as a predictor for bleaching event (Van Hooidonk et al., 2012; Liu et al., 2013). In our study, the number of days for which HotSpot is > 1 was strongly underestimated when using SST as proxy of $\bar{T}_{L}$ (from 49 to 59 days of difference for Tatakoto depending on the SST dataset used, up to 10-days for Takaroa, and up to 18 days for Manihiki, SM9). In most cases, the various SST datasets used lead to different thermal stress thresholds estimations (SM9). These results highlight that using SST alone as a proxy of $\bar{T}_{L}$ can lead to erroneous conclusions concerning the level of thermal stress experienced by coral reef organisms located in lagoons of poor water renewal. Many populations of coral reef species (either mobile or sessile) found within a region of connected atoll and islands, can be composed of 
individuals that inhabit open well flushed waters and individuals that inhabit closer lagoon waters (e.g., species inhabiting both reef slopes and lagoons). Thermal stress thresholds established on the basis of SST alone are unlikely to provide accurate estimates for a population that is spread in different lagoons.

Modelling lagoon temperature as a function of SST OSTIA- $1^{\circ}$ dataset, $\mathrm{SWH}_{\mathrm{e}}, \mathrm{TR}_{\mathrm{d}}$, and WS reduced the offset between $\mathrm{T}_{\mathrm{m}}$ calculated from SST and $\mathrm{T}_{\mathrm{m}}$ calculated from $\widehat{T}_{L}$ down to $0.1^{\circ} \mathrm{C}$ for Tubuai and Manihiki, $0.2^{\circ} \mathrm{C}$ for Takaroa, and $0.5^{\circ} \mathrm{C}$ for Tatakoto. Similarly, the offset between MMM calculated from SST and MMM calculated from $\widehat{T}_{L}$ was reduced down to $0.1^{\circ} \mathrm{C}$ for Tubuai, Tatakoto, and Takaroa, and $0.0^{\circ} \mathrm{C}$ for Manihiki, but a significant bias remained in the number of days for which HotSpot is $>1$ (SM9). Similar results were obtained when using the MUR-1 ${ }^{\circ}$ dataset, except that in this case the bias in $\mathrm{T}_{\mathrm{m}}$ could not be reduced for Manihiki. These results highlight that knowledge of the main parameters that drive the variability of $\Delta \mathrm{T}$ are needed to characterize the thermal stresses of coral reef populations more accurately than currently in the literature when only SST are used.

\section{Conclusion}

Our study highlights that neither lagoon SST nor oceanic SST are accurate proxies of $\bar{T}_{L}$ for atoll lagoons. Using SST alone as a proxy of $\bar{T}_{L}$ can lead to erroneous conclusions concerning the level of thermal stress experienced by coral reef organisms. Modelling $\Delta \mathrm{T}$ from the drivers of lagoon water renewal and mixing, namely waves, tide, wind, and season, can help reducing the bias. A correction taking into account these factors is therefore necessary when using SST to define organisms' thermal stress thresholds.

\section{Acknowledgement}

Sensors were provided by the SITADEL 2012 project funded by GOPS (www.observatoire-gops.org) and by the Direction des Ressources Marines et Minières in French Polynesia. The study is a result of the MANA (Management of Atolls) project (grant ANR-16-CE32-0004). We are grateful to Gabriel Haumani, Michel Kemake, Asin Rata, Pierre Maere, Hervé Bichet, Martine Rodier and Frederic Faana for their help in deploying the temperature sensors at Takaroa, Tatakoto, and Tubuai. Georgia 
Langdon and Tina Weier (MMR) also helped for the Manihiki sensors early deployment. David Varillon and Jerôme Aucan (IRD Nouméa) provided assistance and advices for all sensor maintenance and for data analysis. Constructive comments from two anonymous reviewers also improved the paper. This is ENTROPIE contribution \#234.

\section{References}

Andréfouët S, Pagès J, Tartinville B, 2001a.Water renewal time for classification of atoll lagoons in the Tuamotu Archipelago (French Polynesia). Coral Reefs, 20: 399-408.

Andréfouët S, Claereboudt M, Matsakis P, Pagès J, Dufour P, 2001b. Typology of atolls rims in Tuamotu archipelago (French Polynesia) at landscape scale using SPOT-HRV images. International Journal of Remote Sensing, 22: 987-1004.

Andréfouët S, Ouillon S, Brinkman R, Falter J, Douillet P, Wolk F, Smith R, Garen P, Martinez E, Laurent V, Lo C, Remoissenet G, Scourzic N, Gilbert A, Deleersnijder E, Steinberg C, Choukroun S, Buestel D, 2006. Review of solutions for 3D hydrodynamic modeling applied to aquaculture in South Pacific atoll lagoons. Marine Pollution Bulletin, 52: 1138-1155.

Andrefouet S, Dutheil C, Menkes CE, Bador M, Lengaigne M, 2015. Mass mortality events in atoll lagoons: environmental control and increased future vulnerability. Global Change Biology, 21 : 195205.

Berkelmans R, Hendee JC, Marshall PA, Ridd PV, Orpin AO, Irvine D, 2002. Automatic weather stations: tools for managing and monitoring potential impacts to coral reefs. Marine Technology Society Journal, 36 (1): 29-38.

Callaghan DP, Nielsen P, Gourlay MR, Ballock TE, 2006. Atoll lagoon flushing forced by waves. Coastal Engineering, 53: 691-704. 
Carrère L, Lyard F, Cancet M, Guillot A, Roblou L, 2012. FES2012: A new global tidal model taking advantage of nearly 20 years of altimetry. In Proceedings of meeting 20 Years of Altimetry, Venice.

Chao Y, Li Z, Farrara JD, Hung P, 2009. Blending Sea Surface Temperatures from Multiple Satellites and In Situ Observations for Coastal Oceans. Journal of Atmospheric and Oceanic Technology, 26: $1415-1426$.

Chin TM, Vazquez-Cuervo J, Armstrong EM, 2017. A multi-scale high-resolution analysis of global sea surface temperature. Remote Sensing of Environment, 200: 154-169. http://dx.doi.org/10.1016/j.rse.2017.07.029.

Doney SC, Ruckelshaus M, Duffy JE, Barry JP, Chan F, English CA, Galindo HM, Grebmeier JA, Hollowed AB, Knowlton N, Polovina J, Rabalais NN, Sydeman WJ, Talley LD, 2012. Climate Change Impacts on Marine Ecosystems. Annual Review of Marine Science, 4: 11-37.

Donlon CJ, Martin M, Stark JD, Roberts-Jones J, Fiedler E, Wimmer W, 2012. The operational sea surface temperature and sea ice analysis (OSTIA) system. Remote Sensing Environ. 116, 140-158, http://dx.doi.org/10.1016/j.rse.2010.10.017.

Dumas F, Le Gendre R, Thomas Y, Andréfouët S, 2012. Tidal flushing and wind driven circulation of Ahe atoll lagoon (Tuamotu Archipelago, French Polynesia) from in situ observations and numerical modelling. Marine Pollution Bulletin, 65: 425-440.

Eakin CM, Morgan JA, Heron SF, Smith TB, Liu G, Alvarez-Filip L, 2010. Caribbean Corals in Crisis: Record Thermal Stress, Bleaching, and Mortality in 2005. PLoS ONE 5, e13969.

Hendee JC, Stabenau E, Florit L, Manzello DP, Jeffris C, 2006. Infrastructure and capabilities of a near real-time meteorological and oceanographic in situ instrumented array, and its role in marine environmental decision support. In Richardson LL, Le Drew EF (Eds.), Remote Sensing of Aquatic Coastal Ecosystem Processes: Science and Management Applications, Springer, Dordrecht, 135-156. 
Lazure P, Dumas F, 2008. An external-internal mode coupling for a 3D hydrodynamical model for applications at regional scale (MARS). Advances in Water Resources, 31: 233-250.

399

400

401

402

403

404

405

406

407

408

409

410

411

412

413

414

415

416

417

Liu G, Rauenzahn JL, Heron SF, Eakin CM, Skirving W, Christensen TRL, 2013. NOAA Coral Reef

Watch 50 km Satellite Sea Surface Temperature-Based Decision Support System for Coral Bleaching Management. NOAA, Washington, D.C., 33 p.

Logan CA, Dunne JP, Eakin CM, Donner SD, 2012. A framework for comparing coral bleaching thresholds. Proceedings of the $12^{\text {th }}$ International Coral Reef Symposium, Cairns, Australia, 9-13 July 2012.

Lowe RJ, Falter JL, 2015. Oceanic Forcing of Coral Reefs. Annual Review of Marine Science, 7: 4366.

McCabe RM, Estrade P, Middleton JH, Melville WK, Roughan M, Lenain L, 2010. Temperature variability in a shallow, tidally isolated coral reef lagoon. Journal of geophysical research, C12: 115 .

McClanahan TR, Ateweberhan M, Sebastian CR, Graham NAJ, Wilson SK, Bruggemann JH, Guillaume MMM, 2007. Predictability of coral bleaching from synoptic satellite and in situ temperature observations. Coral Reefs, $26: 695-701$.

Miller RL, Castillo CED, McKee BA, 2005. Remote sensing of coastal aquatic environments. technologies, techniques and applications Springer, Berlin, 347 p.

Rascle N, Ardhuin F, 2013. A global wave parameter database for geophysical applications. Part 2: Model validation with improved source term parameterization. Ocean Modelling, 70, 174-188.

Smale DA, Wernberg T, 2009. Satellite-derived SST data as a proxy for water temperature in nearshore benthic ecology. Marine Ecology Progress Series, 387: 27-37.

Van Hooidonk, R, Huber, M, 2009. Quantifying the quality of coral bleaching predictions. Coral Reefs, $28: 579-587$. 
Van Hooidonk RJ, Manzello DP, Moye J, Brandt ME, Hendee JC, McCoy C, Manfrino C, 2012. Coral

421 bleaching at Little Cayman, Cayman Islands 2009. Estuarine, Coastal and Shelf Science, 106: 80-84.

\section{Figure captions}

424

Fig. 1: (A) Location of Manihiki (Cook Islands), and Takaroa, Tatakoto and Tubuai (French Polynesia) in the South Pacific Ocean. (B-E): maps of Tatakoto (B), Takaroa (C), Tubuai (D), and Manihiki (E) based on the Millennium mapping project.

Fig. 2: Spatial coverage and resolution of SST series considered in this study, with the example of Manihiki atoll in February 2013. (A) OSTIA-1 ${ }^{\circ}$ (mean of values over the entire window) and OSTIA-

$0.15^{\circ}$ (mean over the dashed box). (B) G1SST- $1^{\circ}$ (mean of values over the entire window) and $432 \mathrm{G} 1 \mathrm{SST}-0.15^{\circ}$ (mean over the dashed box). (C) MUR- $1^{\circ}$ (mean of values over the entire window) and MUR- $0.15^{\circ}$ (mean over the dashed box). (D) MURLAG (i.e., MUR values that fell in the lagoon).

Fig. 3: Time series of $\Delta \mathrm{T}$ on the basis of the "OSTIA-1" ${ }^{\circ "}$ dataset. Positive values of $\Delta \mathrm{T}$ indicate warmer lagoon waters than SST, and vice versa. Red: TAT2, TAK2, MAN3, black: TAT3, TAK3, 
Tables

Table 1: Pearson's correlation between $\bar{T}_{L}$ (Logger) and the various SST series. For each logger, the 441 highest correlations are bolded.

\begin{tabular}{|c|c|c|c|c|c|c|c|}
\hline OgST & OSTIA-1 ${ }^{\circ}$ & $\begin{array}{c}\text { OSTIA- } \\
0.15^{\circ}\end{array}$ & G1SST- $1^{\circ}$ & $\begin{array}{c}\text { G1SST- } \\
0.15^{\circ}\end{array}$ & MUR- $1^{\circ}$ & $\begin{array}{l}\text { MUR- } \\
0.15^{\circ}\end{array}$ & MURLAG \\
\hline TAT1 & 0.83 & 0.83 & 0.79 & 0.76 & 0.83 & 0.82 & 0.82 \\
\hline TAT2 & 0.84 & 0.84 & 0.79 & 0.77 & 0.84 & 0.83 & 0.83 \\
\hline TAT3 & 0.87 & 0.87 & 0.83 & 0.81 & 0.87 & 0.87 & 0.86 \\
\hline TAK1 & 0.92 & 0.92 & 0.87 & 0.81 & 0.91 & 0.90 & 0.92 \\
\hline TAK2 & 0.95 & 0.95 & 0.88 & 0.81 & 0.94 & 0.93 & 0.95 \\
\hline TAK3 & 0.84 & 0.84 & 0.79 & 0.73 & 0.83 & 0.82 & 0.85 \\
\hline MAN1 & 0.82 & 0.81 & 0.53 & 0.44 & 0.72 & 0.67 & 0.73 \\
\hline MAN2 & 0.82 & 0.82 & 0.57 & 0.48 & 0.70 & 0.66 & 0.70 \\
\hline MAN3 & 0.91 & 0.89 & 0.62 & 0.48 & 0.81 & 0.75 & 0.80 \\
\hline TUB3 & 0.97 & 0.97 & 0.94 & 0.91 & 0.97 & 0.96 & 0.97 \\
\hline
\end{tabular}


443

Figures

444

Fig. 1
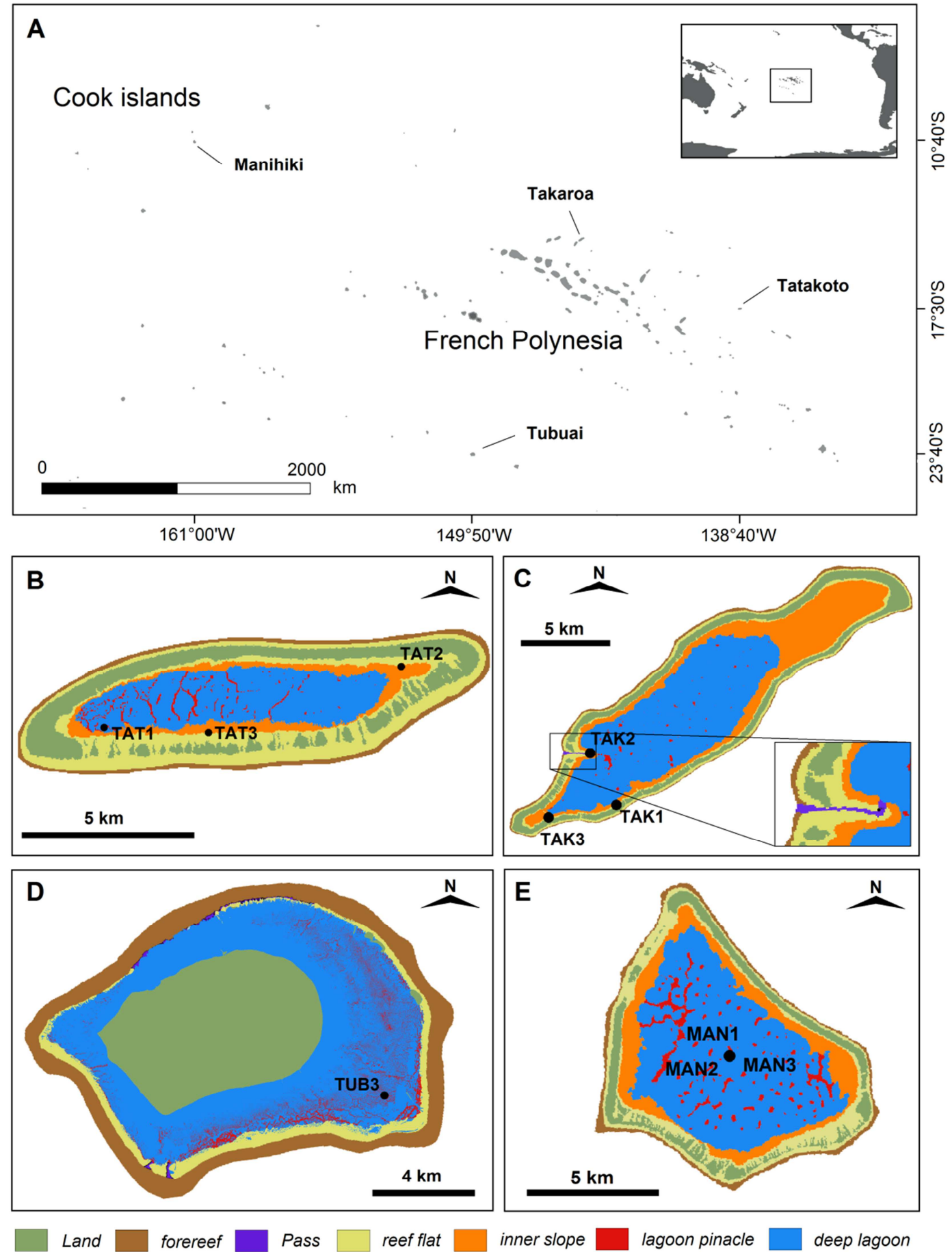
Fig. 2
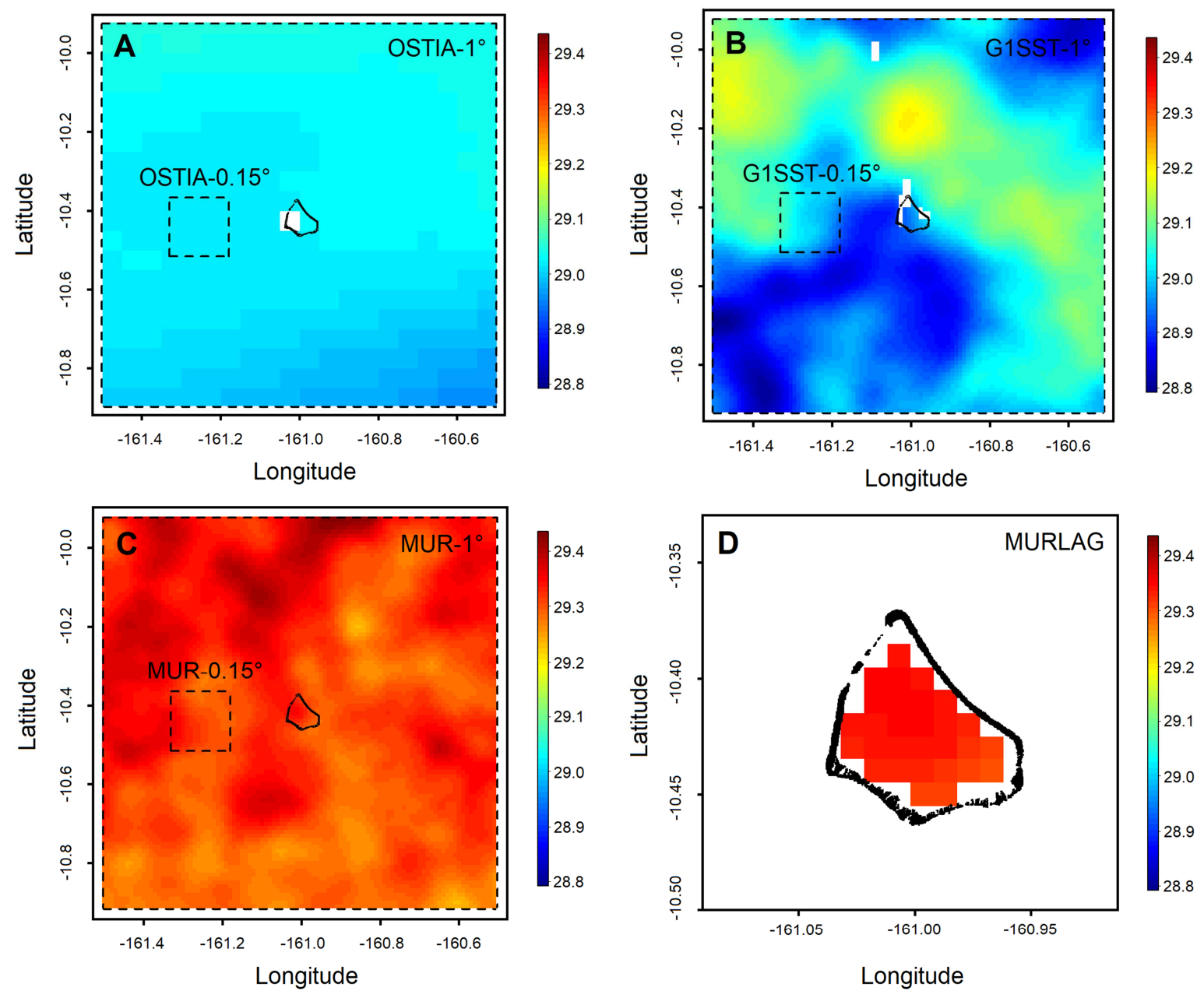
Fig. 3
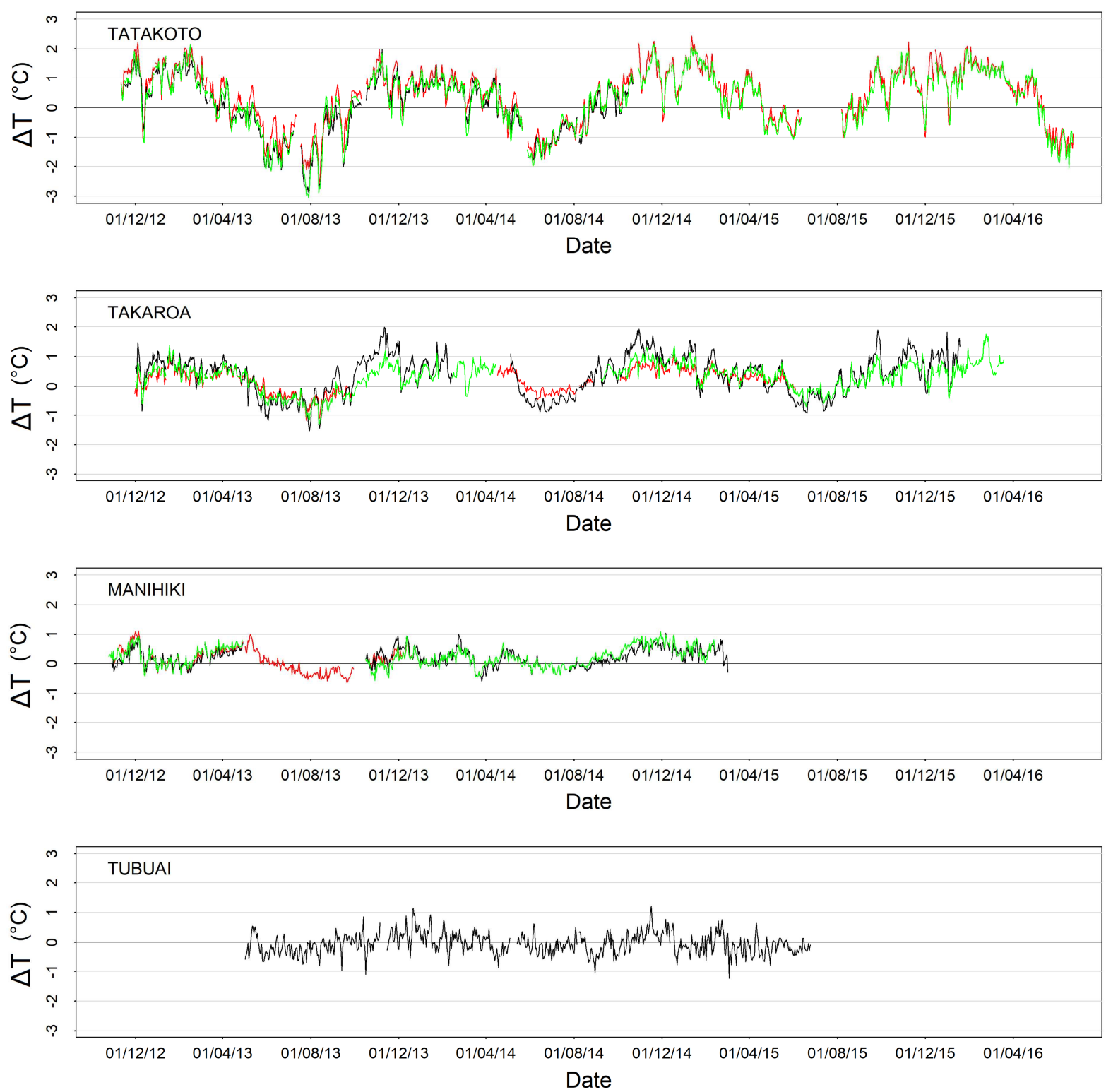

$455 \mathrm{~T}_{\mathrm{L}}$ : Temperature experienced by coral reef organisms. Unit: Degree Celsius $\left({ }^{\circ} \mathrm{C}\right)$.

$456 \bar{T}_{L}$ : Daily mean of $\mathrm{T}_{\mathrm{L}}$. Unit: Degree Celsius $\left({ }^{\circ} \mathrm{C}\right)$.

457 SST: Sea surface temperature. Unit: Degree Celsius $\left({ }^{\circ} \mathrm{C}\right)$. 
$458 \Delta \mathrm{T}$ : Difference between $\bar{T}_{L}$ and SST. Unit: Degree Celsius $\left({ }^{\circ} \mathrm{C}\right)$.

459 SWH: Significant wave height. Unit: Metre (m).

$460 \theta_{\mathrm{m}}$ : Mean wave direction. Unit: Degree $\left(^{\circ}\right)$.

$461 \mathrm{SWH}_{\mathrm{e}}$ : Significant height of waves, excluding waves whose direction is perpendicular to the

462 shoreline of close (emerged) ring only and therefore not supposed to drive lagoon water renewal. Unit:

463 Metre (m).

$464 \mathrm{TR}_{\mathrm{d}}$ : Daily range between highest tide and lowest tide. Unit: Metre $(\mathrm{m})$.

465 MTR: Mean tidal range over the study period. Unit: Metre (m).

466 WS: Wind speed. Unit: Metre per second $\left(\mathrm{m} . \mathrm{s}^{-1}\right)$

$467 T_{v}$ : Seasonal amplitude of $\Delta \mathrm{T}$. Unit: Degree Celsius $\left({ }^{\circ} \mathrm{C}\right)$.

$468 \widehat{T}_{L}$ : Temperature experienced by coral reef organisms as modelled from SST, $T_{v}, \mathrm{SWH}_{\mathrm{e}}, \mathrm{TR}_{\mathrm{d}}$, and WS.

469 Unit: Degree Celsius $\left({ }^{\circ} \mathrm{C}\right)$.

$470 \mathrm{~T}_{\mathrm{m}}$ : The maximal temperature recorded during the study period. Unit: Degree Celsius $\left({ }^{\circ} \mathrm{C}\right)$.

471 MMM: Mean monthly maximum over the study period. Unit: Degree Celsius $\left({ }^{\circ} \mathrm{C}\right)$. 
Supplementary material

473 SM1: Main characteristics of sensors used in this study. T: Temperature, P: Pressure.

\begin{tabular}{|c|c|c|c|c|c|c|}
\hline Location & $\begin{array}{c}\text { Sensor } \\
\text { ID }\end{array}$ & Sensor Type & Measurement & Depth (m) & Deployment time & Frequency \\
\hline Tatakoto & TAT1 & Seabird SBE56 & $\mathrm{T}$ & 1.0 & Nov2012-Jun2016 & $30 \mathrm{~min}$ \\
\hline Tatakoto & TAT2 & Seabird SBE56 & $\mathrm{T}$ & 2.8 & Nov2012-Jun2016 & $30 \mathrm{~min}$ \\
\hline Tatakoto & TAT3 & RBR RBRduo & $\mathrm{T}, \mathrm{P}$ & 3.4 & Nov2012-Oct2014 & $30 \mathrm{~min}$ \\
\hline Tubuai & TUB3 & RBR TWR2050 & $\mathrm{T}, \mathrm{P}$ & 1.2 & Apr2013-Jun2015 & $15 \mathrm{~min}$ \\
\hline Takaroa & TAK1 & Seabird SBE56 & $\mathrm{T}$ & 4 & Nov2012- Mar2016 & $30 \mathrm{~min}$ \\
\hline Takaroa & TAK2 & RBR RBRduo & $\mathrm{T}, \mathrm{P}$ & 4 & Nov2012-Jun2015 & $30 \mathrm{~min}$ \\
\hline Takaroa & TAK3 & Seabird SBE56 & & 2 & Nov2012-Jan2016 & $30 \mathrm{~min}$ \\
\hline Manihiki & MAN1 & Seabird SBE56 & $\mathrm{T}$ & 5 & Oct2012-Fev2015 & $30 \mathrm{~min}$ \\
\hline Manihiki & MAN2 & Seabird SBE56 & $\mathrm{T}$ & 20 & Oct2012-Mar2015 & $30 \mathrm{~min}$ \\
\hline Manihiki & MAN3 & RBR RBRduo & $\mathrm{T}, \mathrm{P}$ & 15 & Oct2012-Dec2013 & $30 \mathrm{~min}$ \\
\hline
\end{tabular}




\section{ACCEPTED MANUSCRIPT}

475 SM2: Maps of MUR SST. Plotted values are the monthly means for February (A, C, E, G) and July

476 (B, D, F, H) around Tatakoto (A and B), Takaroa (C and D), Manihiki (E and F), and Tubuai (G and

477 H). Note the different scale bars.
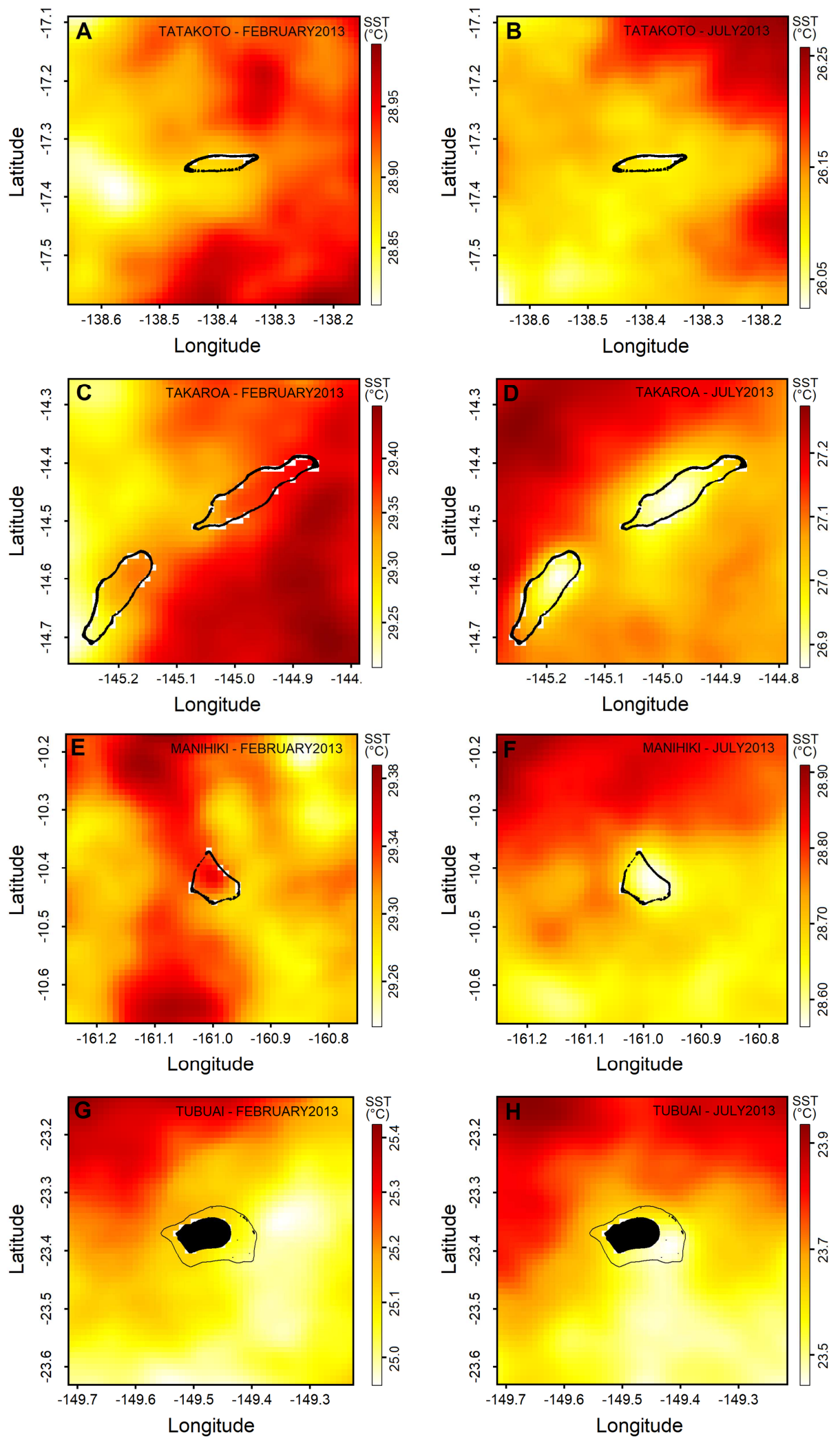
SM3: Plot of values which highlight no apparent collinearity between the daily range between highest
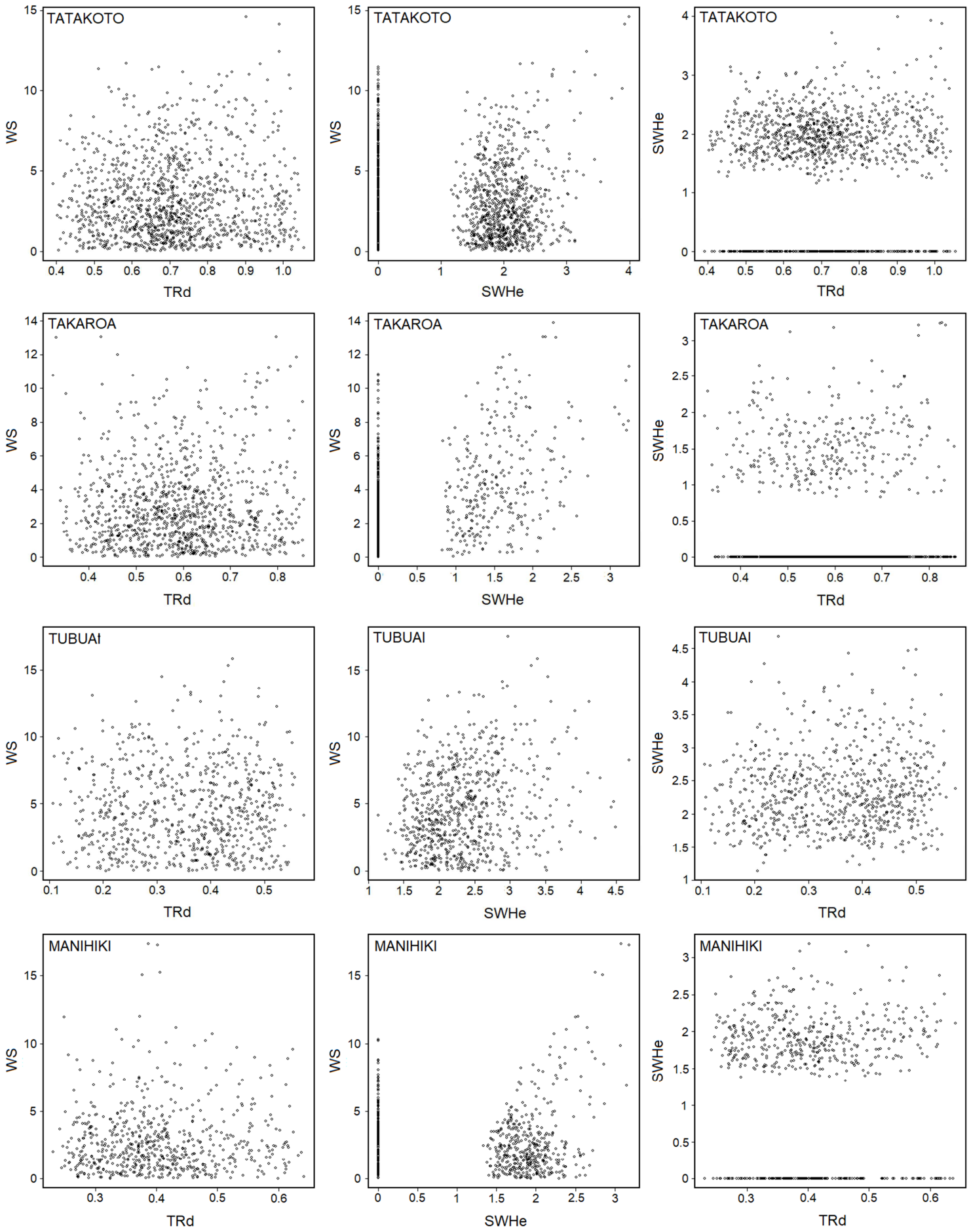

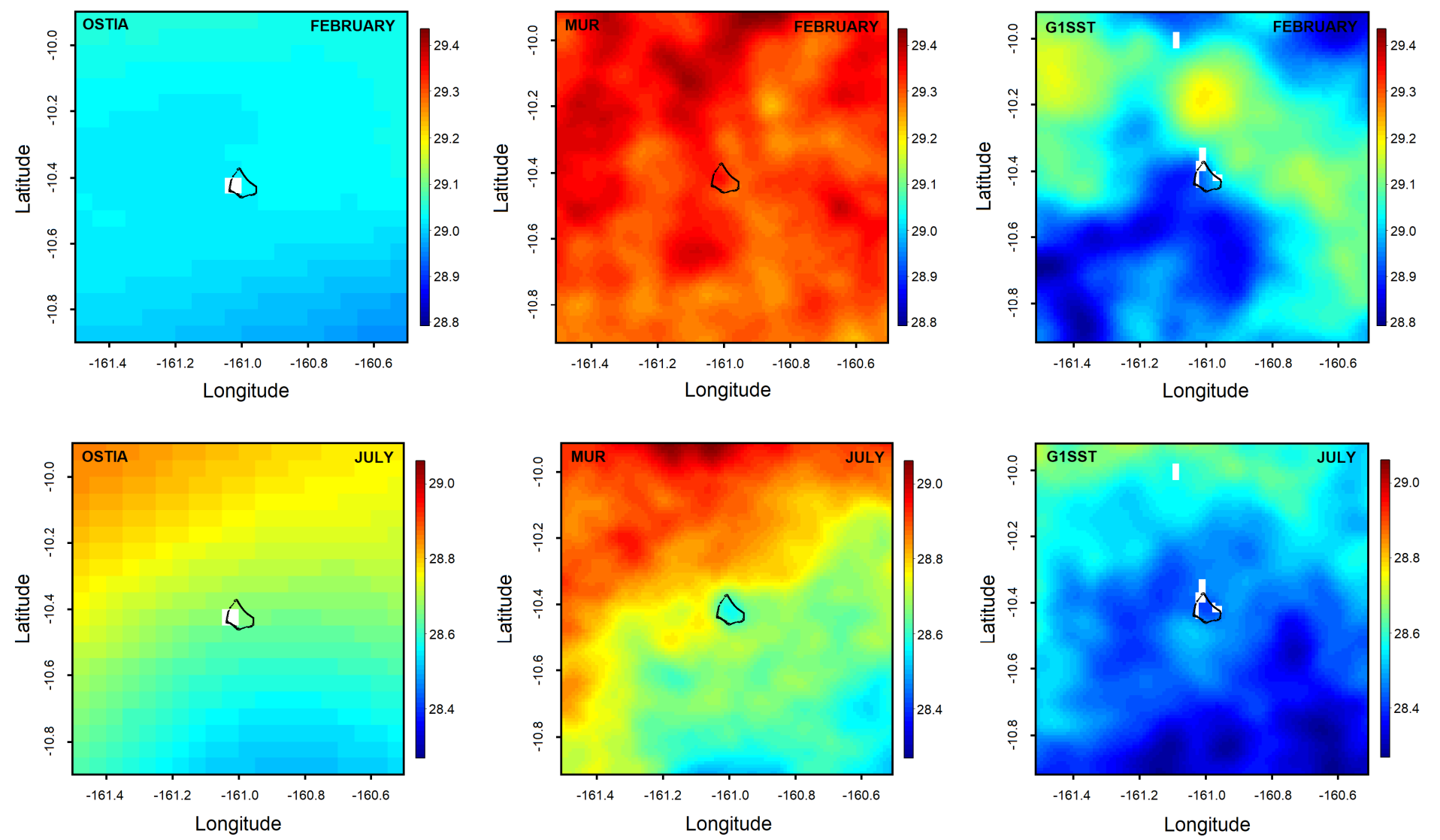
487 SM5: Time series (December 2012 - June 2016) of offshore tide and lagoon water level (upper panel), 488 wind intensity (second panel), offshore wave height and direction (third panel), SST from OSTIA-1 ${ }^{\circ}$, 489 OSTIA- $0.15^{\circ}, \mathrm{G} 1 \mathrm{SST}-1^{\circ}, \mathrm{G} 1 \mathrm{SST}-0.15^{\circ}, \mathrm{MUR}-1^{\circ}, \mathrm{MUR}-0.15^{\circ}$, and MURLAG datasets and lagoon 490 temperature recorded by in situ sensors (lower panel) at the four studied sites. (TAT) Tatakoto (TAK)

491 Takaroa (MAN) Manihiki (TUB) Tubuai. Available at: 10.5281/zenodo.997599

492

493

494 
SM6: Results from modelling $\Delta \mathrm{T}$ as a function of seasonality $\left(\mathrm{T}_{\mathrm{v}}\right)$, significant height of effective waves $\left(\mathrm{SWH}_{\mathrm{e}}\right)$, daily tidal range $\left(\mathrm{TR}_{\mathrm{d}}\right)$, and $\mathrm{Wind}_{\mathrm{s}}$ speed (WS). $\triangle \mathrm{AIC}$ refers to the difference of AIC between models that do consider versus do not consider predictors. Significance of the GAM parameters when considered individually are indicated by $*(\alpha=0.05), * *(\alpha=0.01)$ and $* * *(\alpha=0.001)$. Significance $(\alpha=0.05)$ of the GAM parameters when considered all together are indicated by (1) for $\mathrm{SWH}_{\mathrm{e}},(2)$ for $\mathrm{TR}_{\mathrm{d}}$ and (3) for WS, ordered from the most significant to the less significant. $\mathrm{R}^{2}$ is the proportion of variance of $\Delta \mathrm{T}$ explained by the selected models.

\begin{tabular}{|c|c|c|c|c|c|c|c|c|c|}
\hline \multirow[b]{2}{*}{ logger } & \multirow[b]{2}{*}{ SST data } & \multicolumn{3}{|c|}{ Seasonal trend } & \multicolumn{4}{|c|}{ Intra-seasonal trend } & \multirow[b]{2}{*}{$\mathrm{R}^{2}$} \\
\hline & & $\mathrm{T}_{\mathrm{v}}$ & $\mathrm{C}$ & $\begin{array}{c}\Delta \mathrm{AIC} \\
\text { (season) }\end{array}$ & $\begin{array}{c}\Delta \mathrm{AIC} \\
\left(\mathrm{SWH}_{\mathrm{e}}\right)\end{array}$ & $\begin{array}{l}\Delta \mathrm{AIC} \\
\left(\mathrm{TR}_{\mathrm{d}}\right)\end{array}$ & $\begin{array}{l}\Delta \mathrm{AIC} \\
(\mathrm{WS})\end{array}$ & $\begin{array}{c}\Delta \mathrm{AIC} \\
\left(\mathrm{SWH}_{\mathrm{e}}, \mathrm{TR}_{\mathrm{d}}, \mathrm{WS}\right)\end{array}$ & \\
\hline TAT1 & OSTIA-1 ${ }^{\circ}$ & 1.14 & 77.7 & 898 & $130^{* * *}$ & $5.57^{*}$ & $204^{* * * *}$ & $239^{(3,1)}$ & 0.89 \\
\hline TAT1 & OSTIA- $0.15^{\circ}$ & 1.14 & 77.8 & 908 & $122^{* * * *}$ & $5.28^{*}$ & $195^{* * * * *}$ & $229^{(3,1)}$ & 0.88 \\
\hline TAT1 & G1SST-1 ${ }^{\circ}$ & 1.18 & 76.2 & 815 & $89.7^{* * *}$ & $6.19^{*}$ & $141^{* * * *}$ & $167^{(3,1,2)}$ & 0.85 \\
\hline TAT1 & G1SST-0.15 ${ }^{\circ}$ & 1.19 & 75.4 & 815 & $83.0^{* * * *}$ & $5.35^{*}$ & $124^{\text {***** }}$ & $147^{(3,1,2)}$ & 0.82 \\
\hline TAT1 & MUR-1 $^{\circ}$ & 1.06 & 80.1 & 779 & $102^{* * * *}$ & $4.67^{*}$ & $170^{* * * *}$ & $197^{(3,1,2)}$ & 0.87 \\
\hline TAT1 & MUR-0.15 & 1.05 & 79.8 & 759 & $86.5^{* * * *}$ & $3.40^{\mathrm{ns}}$ & $147^{* * * *}$ & $174^{(3,1)}$ & 0.86 \\
\hline TAT2 & OSTIA-1 $^{\circ}$ & 1.13 & 76.7 & 751 & $145^{* * * *}$ & $10.3^{* * *}$ & $242^{* * * *}$ & $301^{(3,1,2)}$ & 0.90 \\
\hline TAT2 & OSTIA- $0.15^{\circ}$ & 1.13 & 76.9 & 757 & $135^{* * *}$ & $9.60^{* *}$ & $230^{* * * *}$ & $287^{(3,1,2)}$ & 0.90 \\
\hline TAT2 & $\mathrm{G} 1 \mathrm{SST}-1^{\circ}$ & 1.17 & 75.4 & 657 & $95.3^{* * *}$ & $10.4^{* *}$ & $160^{* * *}$ & $201^{(3,1,2)}$ & 0.86 \\
\hline TAT2 & G1SST-0.15 & 1.19 & 74.5 & 680 & $87.3^{* * * *}$ & $9.03^{* * *}$ & $141^{\text {***** }}$ & $176^{(3,1,2)}$ & 0.84 \\
\hline TAT2 & MUR-1 $^{\circ}$ & 1.06 & 79.1 & 632 & $114^{* * * *}$ & $9.41^{* *}$ & $201^{* * * *}$ & $247^{(3,1,2)}$ & 0.89 \\
\hline TAT2 & MUR-0.15 & 1.05 & 78.8 & 634 & $98.2^{* * * *}$ & $7.36^{* *}$ & $173^{* * *}$ & $218^{(3,1,2)}$ & 0.88 \\
\hline TAT3 & OSTIA-1 $^{\circ}$ & 1.13 & 78.1 & 561 & $102^{* * * *}$ & $7.82^{* *}$ & $126^{\text {**** }}$ & $142^{(3,1,2)}$ & 0.92 \\
\hline TAT3 & OSTIA- $0.15^{\circ}$ & 1.12 & 77.9 & 553 & $98.7^{\text {**** }}$ & $7.01^{*}$ & $126^{* * * *}$ & $141^{(3,1)}$ & 0.92 \\
\hline TAT3 & $\mathrm{G} 1 \mathrm{SST}-1^{\circ}$ & 1.18 & 76.4 & 552 & $62.8^{* * *}$ & $8.65^{* *}$ & $89.8^{* * * *}$ & $97.0^{(3,2)}$ & 0.88 \\
\hline TAT3 & G1SST-0.15 & 1.18 & 74.9 & 533 & $62.8^{* * * *}$ & $8.50^{* *}$ & $86.1^{* * * *}$ & $93.7^{(3,2,1)}$ & 0.87 \\
\hline TAT3 & MUR-1 $^{\circ}$ & 1.03 & 81.8 & 520 & $80.3^{* * *}$ & $6.70^{*}$ & $105^{\text {**** }}$ & $118^{(3,1,2)}$ & 0.91 \\
\hline TAT3 & MUR-0.15 & 1.01 & 80.4 & 466 & $71.9^{* * *}$ & $4.87^{*}$ & $98.9^{\text {***** }}$ & $111^{(3,1)}$ & 0.90 \\
\hline TAK1 & OSTIA-1 $^{\circ}$ & 0.54 & 71.9 & -0.46 & $60.9^{* * * *}$ & $-1.76^{\mathrm{ns}}$ & $65.3^{* * * *}$ & $86.6^{(3,1)}$ & 0.90 \\
\hline TAK1 & OSTIA- $0.15^{\circ}$ & 0.54 & 70.4 & 71.9 & $61.0^{* * * *}$ & $-1.31^{\mathrm{ns}}$ & $67.0^{* * *}$ & $87.8^{(3,1)}$ & 0.90 \\
\hline TAK1 & G1SST-1 ${ }^{\circ}$ & 0.51 & 66.9 & -54.0 & $24.9^{* * * *}$ & $0.96^{\text {ns }}$ & $38.8^{* * *}$ & $45.5^{(3,1)}$ & 0.81 \\
\hline
\end{tabular}




\begin{tabular}{|c|c|c|c|c|c|c|c|c|c|}
\hline TAK1 & G1SST-0.15 & 0.50 & 64.9 & 83.3 & $15.7^{* * * *}$ & $3.25^{*}$ & $25.4^{* * * *}$ & $30.8^{(3,1,2)}$ & 0.73 \\
\hline TAK1 & MUR-1 ${ }^{\circ}$ & 0.38 & 82.9 & -31.1 & $41.5^{* * * *}$ & $4.8^{*}$ & $37.9^{* * * *}$ & $61.8^{(1,3,2)}$ & 0.86 \\
\hline TAK1 & MUR-0.15 & 0.37 & 78.4 & 40.1 & $30.6^{* * * *}$ & $5.57^{*}$ & $25.3^{* * *}$ & $45.9^{(1,3,2)}$ & 0.85 \\
\hline TAK2 & OSTIA-1 $^{\circ}$ & 0.41 & 47.5 & 31.98 & $70.1^{* * * *}$ & $7.31^{* *}$ & $53.3^{* * *}$ & $81.3^{(1,3,2)}$ & 0.94 \\
\hline TAK2 & OSTIA- $0.15^{\circ}$ & 0.41 & 47.1 & 80.8 & $72.6^{* * * *}$ & $7.06^{* *}$ & $56.4^{* * *}$ & $83.8^{(1,3,2)}$ & 0.94 \\
\hline TAK2 & G1SST-1 ${ }^{\circ}$ & 0.50 & 41.0 & 140 & $26.6^{* * * *}$ & $3.62^{*}$ & $23.2^{* * * *}$ & $38.1^{(1,3,2)}$ & 0.87 \\
\hline TAK2 & G1SST-0.15 & 0.52 & 42.8 & 209 & $18.5^{* * * *}$ & $3.76^{*}$ & $14.4^{* * *}$ & $25.3^{(1,2,3)}$ & 0.78 \\
\hline TAK2 & MUR-1 ${ }^{\circ}$ & 0.21 & 43.3 & 34.0 & $57.8^{* * * *}$ & $31.0^{* * * *}$ & $27.5^{* * * *}$ & $90.6^{(1,2)}$ & 0.91 \\
\hline TAK2 & MUR-0.15 & 0.24 & 40.4 & 86.3 & $45.4^{* * * *}$ & $22.2^{* * * *}$ & $16.8^{* * * *}$ & $65.3^{(1,2)}$ & 0.90 \\
\hline TAK3 & OSTIA-1 $^{\circ}$ & 0.70 & 93.1 & 233 & $101^{* * *}$ & $1.82^{\mathrm{ns}}$ & $118^{* * *}$ & $162^{(3,1)}$ & 0.87 \\
\hline TAK3 & OSTIA- $0.15^{\circ}$ & 0.69 & 91.8 & 283 & $101^{* * * *}$ & $2.72^{*}$ & $119^{* * * *}$ & $163^{(3,1,2)}$ & 0.87 \\
\hline TAK3 & G1SST-1 ${ }^{\circ}$ & 0.66 & 91.5 & 127 & $49.4^{* * * *}$ & $4.26^{*}$ & $83.0^{* * * *}$ & $98.9^{(3,1,2)}$ & 0.78 \\
\hline TAK3 & G1SST-0.15 & 0.66 & 89.4 & 221 & $36.0^{* * *}$ & $6.34^{* *}$ & $60.7^{* * *}$ & $74.1^{(3,1,2)}$ & 0.71 \\
\hline TAK3 & MUR-1 ${ }^{\circ}$ & 0.58 & 105.2 & 175 & $64.4^{* * * *}$ & $13.2^{* * * *}$ & $80.5^{* * * *}$ & $122^{(3,1,2)}$ & 0.82 \\
\hline TAK3 & MUR-0.15 & 0.57 & 102 & 224 & $51.9^{* * *}$ & $13.6^{* * * *}$ & $63.9^{* * * *}$ & $101^{(3,1,2)}$ & 0.81 \\
\hline TUB3 & OSTIA-1 $^{\circ}$ & 0.19 & 98.0 & 98.8 & $25.3^{* * * *}$ & $0.36^{\mathrm{ns}}$ & $44.5^{\text {**** }}$ & $50.5^{(3,1)}$ & 0.95 \\
\hline TUB3 & OSTIA- $0.15^{\circ}$ & 0.18 & 83.2 & 86.8 & $33.3^{* * *}$ & $3.97^{*}$ & $60.3^{* * *}$ & $76.4^{(3,1)}$ & 0.95 \\
\hline TUB3 & G1SST-1 ${ }^{\circ}$ & 0.24 & 58.4 & 4.21 & $0.97^{\mathrm{ns}}$ & $0.96^{\mathrm{ns}}$ & $17.4^{* * * * *}$ & $17.1^{(3)}$ & 0.89 \\
\hline TUB3 & G1SST-0.15 & 0.27 & 47.4 & 47.9 & $1.26^{\mathrm{ns}}$ & $2.12^{*}$ & $23.6^{* * * * *}$ & $29.1^{(3,2,1)}$ & 0.86 \\
\hline TUB3 & MUR-1 ${ }^{\circ}$ & 0.17 & 79.3 & 37.7 & $43.4^{* * * *}$ & $0.968^{\mathrm{ns}}$ & $118^{* * * * * *}$ & $122^{(3,1,2)}$ & 0.95 \\
\hline TUB3 & MUR-0.15 & 0.16 & 62.6 & 53.6 & $27.8^{* * * *}$ & $3.62^{*}$ & $111^{* * * *}$ & $116^{(3)}$ & 0.93 \\
\hline MAN1 & OSTIA-1 ${ }^{\circ}$ & 0.26 & 82.8 & -177 & $62.3^{* * *}$ & $5.92^{*}$ & $64.7^{* * *}$ & $85.6^{(3,1,2)}$ & 0.69 \\
\hline MAN1 & OSTIA- $0.15^{\circ}$ & 0.25 & 83.4 & -143 & $63.7^{* * * *}$ & $6.54^{* *}$ & $66.0^{* * * *}$ & $86.7^{(3,1,2)}$ & 0.69 \\
\hline MAN1 & $\mathrm{G} 1 \mathrm{SST}-1^{\circ}$ & 0.21 & 82.3 & -143 & $16.0^{* * * *}$ & $-1.79^{\mathrm{ns}}$ & $13.3^{* * * *}$ & $20.2^{(1,3)}$ & 0.17 \\
\hline MAN1 & G1SST-0.15 & 0.19 & 86.6 & -274 & $8.69^{* *}$ & $-1.72^{\mathrm{ns}}$ & $10.3^{* *}$ & $11.7^{(1,3)}$ & 0.00 \\
\hline MAN1 & MUR-1 ${ }^{\circ}$ & 0.19 & 2300 & -106 & $30.0^{* * * *}$ & $15.1^{* * *}$ & $32.8^{* * * *}$ & $53.7^{(2,1,3)}$ & 0.55 \\
\hline MAN1 & MUR-0.15 & 0.16 & -2077 & -118 & $28.6^{\text {**** }}$ & $9.60^{* *}$ & $33.7^{* * *}$ & $50.5^{(3,1,2)}$ & 0.45 \\
\hline MAN2 & OSTIA-1 ${ }^{\circ}$ & 0.29 & 81.5 & -107 & $42.2^{* * *}$ & $1.62^{\mathrm{ns}}$ & $23.1^{* * * *}$ & $46.8^{(1,3)}$ & 0.69 \\
\hline MAN2 & OSTIA- $0.15^{\circ}$ & 0.28 & 82.2 & -74.1 & $42.9^{* * * *}$ & $2.06^{\mathrm{ns}}$ & $25.0^{* * * *}$ & $47.2^{(1,3)}$ & 0.68 \\
\hline MAN2 & G1SST-1 ${ }^{\circ}$ & 0.24 & 80.7 & -155 & $14.5^{\text {**** }}$ & $0.35^{\mathrm{ns}}$ & $-0.24^{\mathrm{ns}}$ & $12.9^{(1)}$ & 0.17 \\
\hline MAN2 & G1SST- $0.15^{\circ}$ & 0.20 & 84.5 & -301 & $7.62^{* *}$ & $1.92^{*}$ & $-0.23^{\mathrm{ns}}$ & $7.85^{(1)}$ & 0.00 \\
\hline MAN2 & MUR-1 ${ }^{\circ}$ & 0.23 & 469 & -61.8 & $14.8^{* * * *}$ & $11.6^{* * * *}$ & $10.9^{* * * * *}$ & $28.1^{(2,1)}$ & 0.49 \\
\hline MAN2 & MUR-0.15 & 0.19 & 106 & -111 & $12.8^{* * * *}$ & $7.7^{* * *}$ & $13.3^{* * * *}$ & $26.2^{(2,1,3)}$ & 0.39 \\
\hline MAN3 & OSTIA- $1^{\circ}$ & 0.29 & 37.0 & -99.9 & $60.5^{\text {**** }}$ & $4.63^{*}$ & $54.7^{* * * *}$ & $72.7^{(3,1,2)}$ & 0.77 \\
\hline
\end{tabular}




\begin{tabular}{|c|c|c|c|c|c|c|c|c|c|}
\hline MAN3 & OSTIA-0.15 $^{\circ}$ & 0.30 & 38.3 & -57.6 & $65.8^{* * *}$ & $4.80^{*}$ & $58.3^{* * * *}$ & $78.3^{(3,1,2)}$ & 0.77 \\
\hline MAN3 & G1SST-1 $^{\circ}$ & 0.39 & 27.5 & 43.9 & $23.8^{* * *}$ & $-1.53^{\text {ns }}$ & $20.0^{* * * *}$ & $27.2^{(1,3)}$ & 0.43 \\
\hline MAN3 & G1SST-0.15 & 0.39 & 29.1 & -9.70 & $17.8^{* * *}$ & $-1.89^{\text {ns }}$ & $17.3^{* * *}$ & $20.7^{(1,3)}$ & 0.19 \\
\hline MAN3 & MUR-1 & 0.21 & 57.1 & 33.1 & $48.5^{* * *}$ & $5.76^{*}$ & $42.0^{* * * *}$ & $58.4^{(1,3,2)}$ & 0.70 \\
\hline MAN3 & MUR-0.15 & 0.21 & 55.1 & 44.2 & $51.0^{* * *}$ & $3.42^{\text {ns }}$ & $42.3^{* * *}$ & $57.8^{(1,3)}$ & 0.62 \\
\hline
\end{tabular}

501 
SM7: Detailed description of offshore wave, tide and wind patterns.

505

506

507

Tidal forcing was low for the four sites, with offshore MTR of $0.71 \mathrm{~m}$ for Tatakoto, $0.59 \mathrm{~m}$ for Takaroa, $0.41 \mathrm{~m}$ for Manihiki, and $0.35 \mathrm{~m}$ for Tubuai. $\mathrm{TR}_{\mathrm{d}}$ ranged from $0.58 \mathrm{~m}$ (Tubuai) to $1.06 \mathrm{~m}$ (Tatakoto) during spring tides. The results of the tidal model for Takaroa were congruent with those obtained at a nearby atoll (Ahe) by Dumas et al. (2012) who validated their tidal model using extensive field data. For all sites, the lagoon water level followed a semi-diurnal trend induced by tide (see time-series of measurements in Supplementary material SM5), but delays from several minutes to hours were recorded between lagoon's high tide and offshore ocean's high tide depending on lagoon closure.

Offshore wave regimes were contrasted between sites, with waves from South-Southeast prevalent from April to November at Tatakoto, Takaroa and Manihiki. From December to March, waves were usually from North-Northeast at Tatakoto, Takaroa and Manihiki. By contrast, high waves from the south were prevalent most of the year at Tubuai. Episodic events of high $\mathrm{SWH}_{\mathrm{e}}$ increased lagoon water level at all sites (see time-series of measurements in Supplementary material SM5). This pattern was however more pronounced for Tatakoto, whose lagoon's water level as well as the semi-diurnal oscillation due to tides decreased markedly during prolonged periods of low waves from the south, indicating very weak connection between the open ocean and lagoon during these periods. By contrast, this pattern was less evident at Takaroa where the highest waves, from South-Southeast, were of lower height than in Tatakoto. This is likely because Takaroa is protected by other nearby atolls located further south in the Tuamotu Archipelago as it has been shown for Ahe atoll, westward from Takaroa (Andréfouët et al., 2012).

For all sites, wind regimes were mostly composed of alternate southeasterlies and northeasterlies, with short windless periods (usually $<3-5$ days, see time-series of measurements in Supplementary material SM5). Southeasterlies were prominent during the Austral winter and northeasterlies during the summer, in agreement with the main wind regimes defined for Ahe atoll (Thomas et al., 2014). These wind regimes are typical for the Central Pacific. However, Tubuai, the southest site, was usually 
530 subject to higher wind speed $\left(6.55 \pm 2.55 \mathrm{~m} . \mathrm{s}^{-1}\right.$, mean $\left.\pm \mathrm{sd}\right)$ than other sites. Tatakoto and Takaroa

531 displayed similar wind regimes, with mean ( $\pm \mathrm{sd}$ ) wind speed of $6.22 \pm 2.13 \mathrm{~m} . \mathrm{s}^{-1}$ and $6.15 \pm 2.14 \mathrm{~m} . \mathrm{s}^{-}$

$532{ }^{1}$ respectively. Manihiki was subject to lower wind than other sites $\left(5.51 \pm 2.14 \mathrm{~m} \cdot \mathrm{s}^{-1}\right)$.

533

534 References

535 Andréfouët S, Ardhuin F, Queffeulou P, Le Gendre R, 2012. Island shadow effects and the wave

536 climate of the Western Tuamotu Archipelago (French Polynesia) inferred from altimetry and

537 numerical model data. Marine Pollution Bulletin, 65: 415-424.

538 Thomas Y, Dumas F, Andréfouët S, 2014. Larval dispersal modelling of pearl oyster Pinctada 539 margaritifera following realistic environmental and biological forcing in Ahe atoll lagoon. PloS one, 9: 540 e95050. 

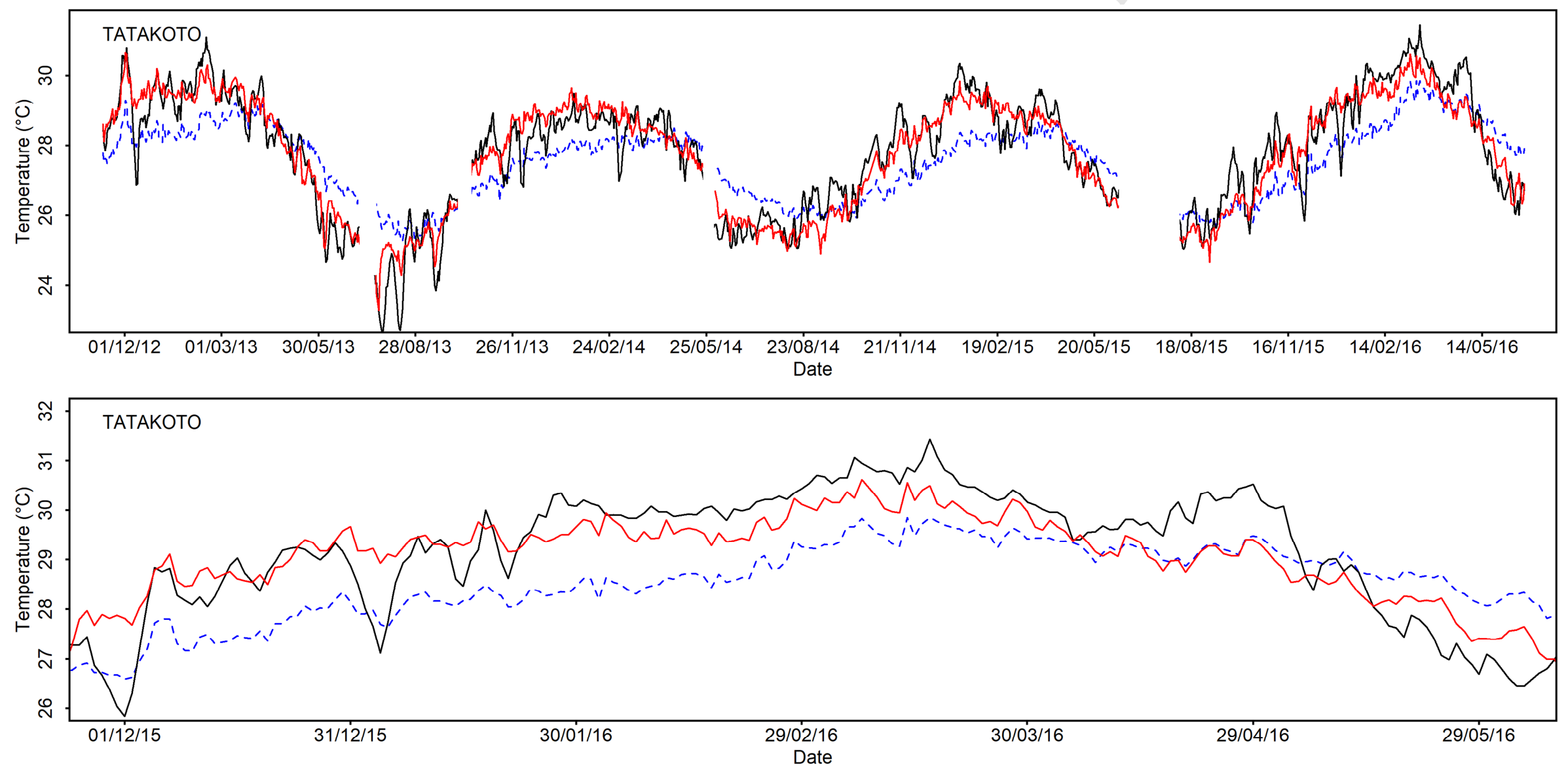


\section{ACCEPTED MANUSCRIPT}

545 SM9: maximal daily mean temperature $\left(\mathrm{T}_{\mathrm{m}}\right)$ and mean monthly maximum (MMM), calculated from

$546 \bar{T}_{L}$ and from SST. In brackets are the values of $\mathrm{T}_{\mathrm{m}}$ and MMM calculated from modelled $\widehat{T}_{L}$.

\begin{tabular}{|c|c|c|c|c|}
\hline Site & Data source & $\mathrm{T}_{\mathrm{m}}$ & MMM & $\begin{array}{c}\text { Number of days } \\
\text { hotspot > } 1\end{array}$ \\
\hline Tubuai & TUB3 & 27.9 & 27.1 & 0 \\
\hline Tubuai & SST OSTIA- $1^{\circ}$ & $27.8(27.8)$ & $26.9(27.0)$ & $0(0)$ \\
\hline Tubuai & SST OSTIA- $0.15^{\circ}$ & $27.8(27.9)$ & $26.9(27.0)$ & $0(0)$ \\
\hline Tubuai & SST G1SST $-1^{\circ}$ & $27.9(28.0)$ & $27.0(27.0)$ & $0(0)$ \\
\hline Tubuai & SST G1SST- $0.15^{\circ}$ & $27.9(28.1)$ & $27.0(27.1)$ & $0(0)$ \\
\hline Tubuai & SST MUR-1 ${ }^{\circ}$ & $27.6(27.8)$ & $27.0(27.0)$ & $0(0)$ \\
\hline Tubuai & SST MUR- $0.15^{\circ}$ & $27.8(27.9)$ & $27.0(27.1)$ & $0(0)$ \\
\hline Tubuai & SST MURLAG-500m & 27.8 & 27.0 & 0 \\
\hline Tatakoto & TAT1 & 31.4 & 29.2 & 61 \\
\hline Tatakoto & SST OSTIA- $1^{\circ}$ & $29.9(30.9)$ & $28.7(29.3)$ & $6(18)$ \\
\hline Tatakoto & SST OSTIA- $0.15^{\circ}$ & $29.9(30.9)$ & $28.7(29.3)$ & $6(17)$ \\
\hline Tatakoto & $\mathrm{SST} \mathrm{G}_{\mathrm{SST}}-1^{\circ}$ & $30.0(30.9)$ & $28.6(29.3)$ & $7(21)$ \\
\hline Tatakoto & SST G1SST $-0.15^{\circ}$ & $29.9(31.0)$ & $28.6(29.2)$ & $12(27)$ \\
\hline Tatakoto & SST MUR- $1^{\circ}$ & $29.8(30.9)$ & $28.7(29.3)$ & $2(17)$ \\
\hline Tatakoto & SST MUR- $0.15^{\circ}$ & $29.9(30.8)$ & $28.8(29.3)$ & $3(19)$ \\
\hline
\end{tabular}


ACCEPTED MANUSCRIPT

\begin{tabular}{|c|c|c|c|c|}
\hline Tatakoto & SST MURLAG-500m & 29.9 & 28.7 & 5 \\
\hline Takaroa & TAK1 & 30.8 & 29.4 & 11 \\
\hline Takaroa & SST OSTIA- $1^{\circ}$ & $30.0(30.6)$ & $29.0(29.5)$ & $1(3)$ \\
\hline Takaroa & SST OSTIA- $0.15^{\circ}$ & $30.1(30.6)$ & $29.0(29.5)$ & $1(4)$ \\
\hline Takaroa & SST G1SST- $1^{\circ}$ & $30.4(30.9)$ & $28.9(29.5)$ & $6(7)$ \\
\hline Takaroa & SST G1SST-0.15 & $30.5(31.0)$ & $29.0(29.5)$ & $12(19)$ \\
\hline Takaroa & SST MUR-1 ${ }^{\circ}$ & $30.2(30.6)$ & $29.1(29.4)$ & $2(2)$ \\
\hline Takaroa & SST MUR-0.15 & $30.5(30.8)$ & $29.1(29.4)$ & $7(8)$ \\
\hline Takaroa & SST MURLAG-500m & 30.2 & 29.2 & 4 \\
\hline Manihiki & MAN1 & 30.6 & 29.4 & 19 \\
\hline Manihiki & SST OSTIA- $1^{\circ}$ & $30.3(30.5)$ & $29.2(29.4)$ & $1(3)$ \\
\hline Manihiki & SST OSTIA- $0.15^{\circ}$ & $30.4(30.6)$ & $29.2(29.4)$ & $1(2)$ \\
\hline Manihiki & SST G1SST-1 ${ }^{\circ}$ & $30.8(31.1)$ & $29.2(29.3)$ & $20(26)$ \\
\hline Manihiki & SST G1SST-0.15 & $31.3(31.5)$ & $29.2(29.3)$ & $29(39)$ \\
\hline Manihiki & SST MUR- $1^{\circ}$ & $30.7(30.9)$ & $29.3(29.4)$ & $3(1)$ \\
\hline Manihiki & SST MUR- $0.15^{\circ}$ & $31.5(31.6)$ & $29.3(29.4)$ & $4(5)$ \\
\hline Manihiki & SST MURLAG-500m & 30.7 & 29.2 & 11 \\
\hline
\end{tabular}

